\title{
PENGARUH ASAL BENIH TIMOHO (Kleinhovia hospita L) TERHADAP PERTUMBUHAN BIBIT DI TINGKAT PERSEMAIAN
}

The effect of Timoho (Kleinhovia hospita L) seeds' origin on seed growth in the nursery

\author{
Rafelinta Daradwinta ${ }^{1}$, Ragil Pinasti², Lukman Hakim ${ }^{3}$ \\ ${ }^{1,2}$ Fakultas Biologi, Universitas Gadjah Mada, \\ Jl. Teknika Selatan, Senolowo, Sinduadi, Mlati, Sleman, Yogyakarta, Indonesia \\ email penulis korespondensi: rafelintadaradwinta@mail.ugm.ac.id
}

${ }^{3}$ Kontributor Utama, ${ }^{3}$ Balai Besar Penelitian dan Pengembangan Bioteknologi dan Pemuliaan Tanaman Hutan, Jl. Palagan Tentara Pelajar Km.15, Purwobinangun, Pakem, Sleman, Yogyakarta, Indonesia

Tanggal diterima: 07 Februari 2020, Tanggal direvisi: 18 Februari 2020, Disetujui terbit: 30 Juni 2020

\begin{abstract}
Timoho (Kleinhovia hospita) wood is one of the raw materials for keris sheath having high aesthetic and economic values. Due to the exploitation of keris raw material that outmatches its planting activities, this type of tree is already hard to find in the Special Region of Yogyakarta, so this research aims to determine the effect of Timoho seeds' origin towards the quality of seedling growth, so it can be used as a standard in determining candidates for generative propagation. The genetic material in the form of seeds in this study came from the parent trees grown in Bulaksumur region (1 tree) and Purwobinangun region (2 trees), Yogyakarta. The research stages conducted were seed extraction, seed scarification, germination in the petri dish, and seedlings planting in polybags. The result showed that the viability of seeds from Bulaksumur was $80 \%$ while the viability of seeds from Purwobinangun was $68 \%$. Observation and measurement of seedling stem length and the number of leaves every 2 weeks for 42 days showed that timoho seedling from Purwobinangun had a higher leaf number $(19,11 \pm 2,66$ blade and a longer stem length $(11,54 \pm 2,77 \mathrm{~cm})$ than seedling from Bulaksumur, which is 0,59 \pm 1,07 blade and 7,59 $\pm 1,17 \mathrm{~cm}$, respectively. Based on the results of this study, it is concluded that there is a possibility of selfing on timoho's tree from Bulaksumur which caused the growth of seedlings from Bulaksumur is lower than seedlings from Purwobinangun.
\end{abstract}

Keywords: generative propagation, selfing, sustainability, viability

\begin{abstract}
ABSTRAK
Kayu timoho (Kleinhovia hospita) merupakan bahan baku warangka keris yang memiliki nilai estetis dan ekonomi tinggi. Adanya eksploitasi pada bahan baku keris yang tidak diimbangi dengan kegiatan penanaman, maka pohon timoho semakin sulit ditemukan di wilayah Daerah Istimewa Yogyakarta. Oleh karena itu, penelitian ini bertujuan untuk mengetahui pengaruh habitat asal pohon induk timoho terhadap kualitas pertumbuhan bibit sehingga dapat dijadikan standar dalam penentuan kandidat perbanyakan generatif. Penelitian ini dilakukan di persemaian kantor B2P2BPTH Yogyakarta. Materi genetik berupa biji dalam penelitian ini berasal dari satu pohon induk di Bulaksumur dan dua pohon induk dari Purwobinangun, Yogyakarta. Tahapan penelitian yang dilakukan meliputi ekstraksi biji, skarifikasi, perkecambahan pada media petri dish, dan persemaian dalam polybag. Hasil penelitian menunjukkan viabilitas biji dari Bulaksumur sebesar $80 \%$ sedangkan dari Purwobinangun sebesar 68\%. Pengamatan dilakukan setiap 2 minggu selama 42 hari menunjukkan bahwa jumlah daun bibit timoho dari Purwobinangun memiliki rata-rata jumlah daun $(19,11 \pm$ 2,66 helai) dan panjang batang $(11,54 \pm 2,77 \mathrm{~cm})$ lebih baik dibandingkan dengan rata-rata jumlah daun dan panjang batang bibit timoho dari Bulaksumur (10,59 \pm 1,07 helai dan 7,59 $\pm 1,17 \mathrm{~cm})$. Berdasarkan hasil penelitian ini, dapat disimpulkan bahwa terdapat kemungkinan adanya selfing pada pohon di Bulaksumur yang menyebabkan pertumbuhan bibit timoho Bulaksumur lebih rendah dibandingkan bibit Purwobinangun.
\end{abstract}

Kata kunci: perbanyakan generatif, selfing, kelestarian, viabilitas

\section{PENDAHULUAN}

Indonesia merupakan negara dengan karakteristik kepulauan yang terdiri dari 17.000 pulau dengan tingkat keanekaragaman flora dan fauna dalam jumlah yang tinggi (Sutoyo, 2010).
Berdasarkan data dari Portal Informasi Indonesia (2018) mencatat bahwa Indonesia turut berkontribusi terhadap keanekaragaman hayati di dunia, 40.000 dari total spesies flora tumbuhan berbiji dan 8.157 spesies fauna vertebrata di dunia berasal dari Indonesia. 
Karakteristik iklim tropis yang dimiliki oleh Indonesia turut memberikan pengaruh terhadap tingkat keragaman hayati flora dan fauna. Selain pengaruh tersebut, proses pembentukan berbagai pulau di Indonesia sangat berperan terhadap tingkat keragaman hayati di Indonesia. Proses yang menyatukan bagian barat Indonesia dengan benua Asia serta bagian timur dengan benua Australia menyebabkan Indonesia menjadi tempat terjadinya perpindahan flora dan fauna dari kedua benua tersebut (Kusmana \& Hikmat, 2015).

Keanekaragaman hayati meliputi seluruh bentuk kehidupan dimulai pada tingkat gen, spesies tumbuhan, hewan, dan mikroorganisme. Seiring dengan berjalannya waktu, tingkat keanekaragaman hayati di Indonesia terus mengalami penurunan. Kondisi tersebut tidak terlepas dari kenyataan bahwa hutan tropis Indonesia sebagai sumber keanekaragaman hayati telah menyusut, dan lahan pertanian mengalami degradasi baik kualitas maupun kuantitasnya (Sutoyo, 2010). Salah satu penyebab kemerosotan tersebut disebabkan oleh adanya pengelolaan sumber daya alam yang kurang memperhatikan prinsip keberlanjutan. Keanekaragaman hayati berperan sangat strategis dalam mengendalikan krisis lingkungan, potensi sumber bahan pangan dan obat-obatan serta jasa lingkungan dalam menjaga keseimbangan ekosistem alam (Njurumana et al., 2014).

Daerah Istimewa Yogyakarta (DIY) merupakan salah satu daerah di Indonesia yang memiliki tingkat keanekaragaman hayati sangat beragam. Keanekaragaman flora dan fauna ditemukan pada setiap wilayah DIY mencakup Sleman, Bantul, Gunung Kidul, Kulon Progo, dan Kota Yogyakarta. Keberagaman jenis bioma yang dapat ditemukan di DIY sangat menunjang kehidupan flora dan fauna. Beberapa jenis bioma pada ekosistem terestrial yang dapat ditemukan di DIY meliputi bioma subalpin, hutan pegunungan, dataran tinggi, dataran rendah, karst, dan gumuk pasir (BLH, 2016).
Kleinhovia hospita (timoho) merupakan salah satu tanaman khas yang dapat ditemukan di DIY. Timoho telah digunakan sebagai obat tradisional di bagian Malaysia, Indonesia, dan Papua Nugini untuk mengobati kudis. Kandungan senyawa bioaktif berupa cyanogen yang ditemukan pada timoho menunjukan aktivitas antitumor serta bagian kambium dapat dimanfaatkan sebagai obat pneumonia. Beberapa senyawa bioaktif yang berhasil diisolasi meliputi scopoletin, quersetin, rutin dan kaempferol (Arung et al., 2009). Penelitian yang telah dilakukan Djabir, Arsyad, Sartini, dan Lallo (2017) menunjukkan bahwa timoho dapat digunakan sebagai obat hepatitis karena memiliki kandungan senyawa cycloartenol yang termasuk ke dalam golongan triterpen (Kleinhospitines $A-D$ ) yang mampu melindungi sel-sel hati dari pengaruh radikal bebas $\mathrm{H}_{2} \mathrm{O}_{2}$ oksidatif.

Timoho memiliki nilai ekonomi dan budaya yang tinggi bagi masyarakat Jawa, terutama di Daerah Istimewa Yogyakarta. Karakteristik tekstur kayu yang ringan dan lunak membuat timoho dimanfaatkan sebagai gagang tombak dan warangka keris karena menghasilkan corak estetik yang disebut pellet oleh masyarakat Yogyakarta (Hakim, Yuliah, \& Adinugraha, 2019; Kehati DIY, 2017). Berdasarkan kegunaan timoho yang terus dimanfaatkan oleh masyarakat sekitar DIY maka sangat penting untuk memastikan keberadaan jenis ini secara lestari. Oleh karena itu, penelitian ini bertujuan untuk mengetahui pengaruh habitat asal pohon induk timoho terhadap kualitas pertumbuhan biji sehingga dapat dijadikan acuan dalam penentuan kandidat perbanyakan secara generatif.

\section{BAHAN DAN METODE}

\section{A. Lokasi dan waktu penelitian}

Kegiatan penelitian dilaksanakan pada tanggal 8 Juli s.d. 13 September 2019 di Kantor Balai Besar Penelitian dan Pengembangan Bioteknologi dan Pemuliaan Tanaman Hutan (B2P2BPTH) Yogyakarta. Pengambilan biji dari 
pohon induk timoho yang berada di Fakultas Kehutanan UGM (Bulaksumur) dan Arboretum Kantor B2P2BPTH

Yogyakarta (Purwobinangun).

\section{B. Bahan dan alat}

Bahan utama yang digunakan dalam penelitian ini adalah biji timoho yang berasal dari Purwobinangun dan Bulaksumur, Yogyakarta. Biji dipanen pada 6-8 Juli 2019. Biji yang digunakan merupakan biji yang sudah dewasa dengan karakteristik kulit biji berwarna coklat.

Bahan yang digunakan untuk perkecambahan biji timoho meliputi tisu, air panas, dan fungisida, Bahan yang digunakan untuk pertumbuhan dalam tingkat persemaian meliputi polybag, pasir, tanah, kompos, dan fungisida.

Alat yang digunakan pada penelitian ini meliputi petri dish sebagai media perkecambahan biji, thermometer untuk mengukur temperatur udara, hygrometer sebagai pengukur kelembaban udara, luxmeter untuk mengukur intensitas cahaya, soiltester untuk mengukur suhu tanah dan kelembaban tanah serta $\mathrm{pH}$ tanah, dan altimeter digunakan sebagai pengukur ketinggian lahan.

\section{Metode}

Penelitian ini dilakukan melalui beberapa tahapan utama antara lain pengambilan sampel biji timoho, ekstraksi biji, skarifikasi, pengamatan perkecambahan biji dalam petri dish, dan pengamatan pertumbuhan bibit dalam media polybag. Pengambilan buah timoho berasal dari pohon induk di Bulaksumur (1 pohon) dan Purwobinangun (2 pohon) menggunakan gunting galah, kemudian masingmasing buah dari pohon induk yang berbeda asal habitat ditampung dalam kantung plastik dengan ukuran $35 \times 45 \mathrm{~cm}$. Ekstraksi buah timoho dilakukan dengan cara membuka kulit buah sehingga didapatkan biji dari pohon timoho kemudian dimasukkan dalam toples yang berbeda berdasarkan habitat asal pohon induk.

Biji timoho yang sudah melalui tahap ekstraksi, dilakukan penimbangan dengan berat yang sama untuk mengetahui jumlah biji masing-masing per satuan berat (gr). Selanjutnya, dilakukan pematahan dormansi pada biji timoho menggunakan metode skarifikasi. Skarifikasi dilakukan dengan perendaman biji dalam air panas selama 24 jam. Setelah 24 jam, biji dengan karakteristik tenggelam dalam air dipindah ke media petri dish. Menurut Farhana, Ilyas, dan Budiman) (2013) perendaman biji pada beberapa tanaman dengan air panas dapat meningkatkan daya kecambah.

Perkecambahan dalam media petri dish dilakukan dengan mengisi 25 biji timoho pada setiap petri dish yang sudah disiapkan. Perlakuan ulangan dilakukan sejumlah 5x pada kedua habitat asal timoho sehingga terdapat 10 media petri dish. Perkecambahan pada biji timoho sangat riskan terhadap adanya gangguan fungi yang dapat menghambat pertumbuhan sehingga perlu dilakukan pemeliharaan dengan penyemprotan fungisida. Penyemprotan fungisida dilakukan pada biji timoho yang berada di media petri dish. Pengamatan perkecambahan dilakukan di greenhouse selama 14 hari.

Analisis fisikokimia dilakukan dengan pengamatan pada beberapa parameter meliputi suhu udara, suhu tanah, kelembaban udara, kelembaban tanah, $\mathrm{pH}$ tanah, intensitas cahaya, ketinggian lahan, dan tekanan udara di masingmasing habitat asal pohon timoho. Pengamatan perkecambahan dilanjutkan dengan pemindahan bibit ke dalam media polybag. Karakteristik bibit yang dapat dipindahkan yaitu memiliki jumlah minimal 2 daun dan panjang minimal 5 $\mathrm{cm}$. Media dalam polybag berupa kompos, pasir, dan tanah dengan perbandingan volume berturut-turut 3:1:1. Pengamatan pertumbuhan tinggi batang dan jumlah daun bibit timoho dilakukan setiap 2 minggu selama kurun waktu 42 hari. 


\section{Analisis}

Data pengukuran dikumpulkan dan dianalisis untuk melihat viabilitas/daya kecambah biji, kecepatan berkecambah, dan persen hidup dengan formula sebagai berikut :

Viabilitas (DK): $\frac{\mathrm{JK}}{\mathrm{JC}}$ X $100 \%$

Keterangan:

JK: jumlah biji yang berkecambah

JC: Jumlah biji yang dikecambahkan

Kecepatan berkecambah:

Keterangan:

$$
\frac{\mathrm{n} 1 \mathrm{~h} 1+\mathrm{n} 2 \mathrm{~h} 2+\mathrm{n} 3 \mathrm{~h} 3+\cdots+\text { nihi }}{\mathrm{n} 1+\mathrm{n} 2+\mathrm{n} 3+\cdots+\mathrm{ni}}
$$

ni : jumlah biji yang berkecambah pada hari ke-i

hi : jumlah hari yang diperlukan untuk mencapai jumlah kecambah ke-i

(Mashudi et al., 2005)

Presentase perkecambahan selama 14 hari pengamatan menggunakan perhitungan sebagai berikut :

$$
\mathrm{PP}(\%)=\frac{n}{N} \mathrm{X} 100 \%
$$

Keterangan:

PP: Presentase perkecambahan

$\mathrm{N}$ : Jumlah biji yang berkecambah

$\mathrm{N}$ : Jumlah biji yang diuji

(Sutopo, 2002).

\section{HASIL DAN PEMBAHASAN}

\section{A. Pengumpulan, ekstraksi, dan skarifikasi biji timoho}

Buah timoho yang sudah masak ditandai dengan karakteristik warna coklat dan struktur kering. Buah masak dipanen menggunakan gunting galah dan masing-masing buah dari lokasi yang berbeda dimasukkan ke dalam wadah plastik ukuran $35 \times 45 \mathrm{~cm}$. Jumlah buah yang diambil dari masing-masing pohon diperkirakan kurang lebih 250 biji. Ekstraksi buah dilakukan dengan proses pengelupasan kulit buah sehingga didapatkan biji timoho. Karakteristik biji yang berasal dari pohon induk di Purwobinangun berwarna lebih gelap dibandingkan dengan biji dari pohon induk di Bulaksumur. Biji yang telah diekstraksi kemudian ditimbang dan diperoleh berat 10,18 g dengan jumlah biji sebanyak 1025 biji dari
Bulaksumur, sedangkan dengan berat yang sama didapatkan biji sebanyak 967 biji dari Purwobinangun. Hal ini menandakan bahwa satu biji dari pohon timoho asal daerah Purwobinangun lebih berat daripada biji dari Bulaksumur.

Ukuran berat suatu biji memberikan gambaran mengenai kemampuan pertumbuhan dari biji tersebut. Penelitian yang dilakukan oleh Deb dan Sundriyal (2017) menunjukkan bahwa biji yang memiliki ukuran lebih berat memiliki kemampuan germinasi dan pertumbuhan yang lebih tinggi dibandingkan dengan biji yang berukuran ringan. Kondisi tersebut sudah sesuai dengan karakteristik biji timoho pada daerah habitat Bulaksumur dan Purwobinangun. Biji Purwobinangun memiliki berat yang lebih besar dibandingkan dengan biji timoho dari Bulaksumur. Hasil penelitian menunjukkan bahwa pertumbuhan biji dari Purwobinangun menunjukkan pertumbuhan yang lebih optimal.

Karakteristik kulit biji yang keras pada timoho sangat berperan penting terhadap proses perkecambahan. Biji tidak dapat melakukan perkecambahan selama masa dormansi. Untuk itu, biji timoho yang sudah diekstraksi selanjutnya diskarifikasi secara fisik dengan merendamnya dalam air panas selama 24 jam. Perlakuan biji secara fisik dapat berupa perendaman air panas melalui penguapan, pemanasan kering menggunakan oven, dan melalui radiasi sinar ultraviolet. Perendaman biji dalam air panas sebelum ditanam dapat membantu biji melakukan perkecambahan dan menghilangkan patogen yang terbawa pada biji (Situmeang, Purwantoro, \& Sulandari, 2014).

Secara umum, faktor internal yang mempengaruhi perkecambahan biji adalah ukuran dan tingkat kematangannya. Biji yang telah matang akan memiliki cadangan makanan yang cukup untuk pertumbuhan embrio. Skarifikasi dengan air panas memberikan pengaruh nyata terhadap persentase perkecambahan, karena perendaman biji dalam air panas dapat melunakkan kulit biji yang keras sehingga dapat memudahkan proses imbibisi 
dan mempercepat proses perkecambahan (Suhartati \& Alfaizin, 2017). Melalui proses skarifikasi tersebut dapat menghasilkan biji yang bersifat permeabel. Penelitian yang dilakukan Suhartati dan Alfaizin (2017) menunjukkan bahwa waktu berkecambah dan kecepatan kecambah dengan menggunakan teknik skarifikasi perendaman air panas pada suhu $80^{\circ} \mathrm{C}$ selama 24 jam dapat menghasilkan daya kecambah sebesar 76\%. Sedangkan perendaman menggunakan air dingin menghasilkan daya kecambah sebesar 42,11\%, dan tanpa skarifikasi sebesar $40 \%$. Hal tersebut menunjukkan bahwa perendaman dapat membantu meningkatkan proses perkecambahan biji terutama perendaman menggunakan air panas. Penelitian lain menunjukan bahwa skarifikasi menggunakan air panas dengan rentang waktu 12, 36, dan 48 jam berpengaruh nyata terhadap persentase kecambah dengan nilai presentase tertinggi sebesar 28\% dikarenakan perendaman menggunakan air panas mempercepat terjadinya pematahan dormansi pada biji (Sandi, Indriyanto, \& Duryat, 2014).

Proses skarifikasi biji dilakukan dengan tujuan memilih biji dengan kualitas yang baik untuk digunakan pada proses selanjutnya. Setelah 24 jam masa perendaman akan didapati adanya biji yang tenggelam dan mengapung. Biji yang akan dikecambahkan diambil dari biji yang tenggelam dengan asumsi bahwa biji yang tenggelam sudah berhasil mematahkan dormansi, sedangkan biji yang mengapung diasumsikan kulit bijinya masih keras sehingga dikhawatirkan proses imbibisi belum terjadi secara optimal. Pada proses tersebut didapatkan 401 biji timoho Bulaksumur yang tenggelam dari total 967 biji sedangkan dari pohon induk yang berasal dari Purwobinangun didapati biji tenggelam sejumlah 766 biji dari total 1025 biji. Hasil tersebut menunjukkan lebih sedikitnya biji yang tenggelam dari Bulaksumur dibandingkan dari Purwobinangun sehingga dapat diketahui biji dari Purwobinangun memiliki kulit biji yang lebih lunak dibanding dengan biji dari
Bulaksumur, sehingga dormansinya lebih mudah dipatahkan.

\section{B. Pengukuran parameter fisikokimia}

Tabel 1. Pengukuran parameter fisikokimia di Bulaksumur dan Purwobinangun

\begin{tabular}{lcc}
\hline \multirow{2}{*}{ Parameter } & \multicolumn{2}{c}{ Lokasi } \\
\cline { 2 - 3 } & Purwobinangun & Bulaksumur \\
\hline Ketinggian lahan & $353 \mathrm{~m}$ & $157 \mathrm{~m}$ \\
Suhu udara & $28,33^{\circ} \mathrm{C}$ & $28,77^{\circ} \mathrm{C}$ \\
Suhu tanah & $26,33^{\circ} \mathrm{C}$ & $25,67^{\circ} \mathrm{C}$ \\
Kelembaban udara & $34,67 \%$ & $36 \%$ \\
pH & 7 & 7 \\
Intensitas cahaya & 607,67 lux & 424,67 lux \\
\hline
\end{tabular}

Berdasarkan Tabel 1 dapat diketahui bahwa di sekitar pohon induk timoho Purwobinangun memiliki ketinggian lahan, suhu tanah, dan intensitas cahaya yang lebih tinggi berturut-turut yaitu $353 \mathrm{~m}, 26,33^{\circ} \mathrm{C}$, dan 607,67 lux dibandingkan di Bulaksumur berturut-turut yaitu $157 \mathrm{~m}, 25,67^{\circ} \mathrm{C}, 424,67$ lux, sedangkan suhu dan kelembaban udara Bulaksumur berturut-turut yaitu $28,77^{\circ} \mathrm{C}$ dan $36 \%$ lebih tinggi dibandingkan dengan di Purwobinangun yaitu $28,33^{\circ} \mathrm{C}$ dan $34,67 \%$. Faktor ketinggian lahan, iklim, dan tingkat kesuburan tanah sangat berperan penting terhadap tingkat abundansi dan keberagaman suatu spesies tumbuhan (Indrawan, Primack, \& Supriatna, 2007). Selain faktor tersebut, terdapat faktor geografis seperti ketinggian tempat, kemiringan lereng, serta arah suatu habitat yang menghadap ke lereng sangat memberikan pengaruh terhadap tingkat kelembaban, suhu, intensitas cahaya, dan curah hujan (Putra, Ambarwati, Mubyarsih, \& Alesti, 2015).

\section{Perkecambahan biji timoho}

Biji yang tenggelam pada proses skarifikasi dipisahkan dari biji yang mengapung. Selanjutnya, biji yang tenggelam 
baik dari pohon induk di Bulaksumur maupun dari Purwobinangun dimasukkan ke dalam lima petri dish dan masing-masing petri dish berisi 25 biji. Sebelum diisi biji, petri dish telah diberi \pm dua lembar tisu yang sudah dibasahi dengan air bersuhu dingin. Media perkecambahan menggunakan petri dish dikarenakan bahan kaca dari petri dish dapat ditembus oleh cahaya sehingga dapat menunjang pertumbuhan biji timoho dengan baik (Romadloni \& Wicaksono, 2018).
Pemilihan lima petri dish untuk masingmasing pertumbuhan biji timoho dengan asal habitat yang berbeda bertujuan sebagai ulangan dalam penelitian. Setelah seluruh biji dimasukkan ke dalam petri dish maka perlu ditutup untuk menjaga kelembabannya serta diletakkan di greenhouse agar mendapat cahaya matahari secukupnya. Pertumbuhan biji timoho dilakukan pengamatan dalam rentang waktu 14 hari. Hasil pengamatan pertumbuhan biji timoho dapat dilihat pada Gambar 1.

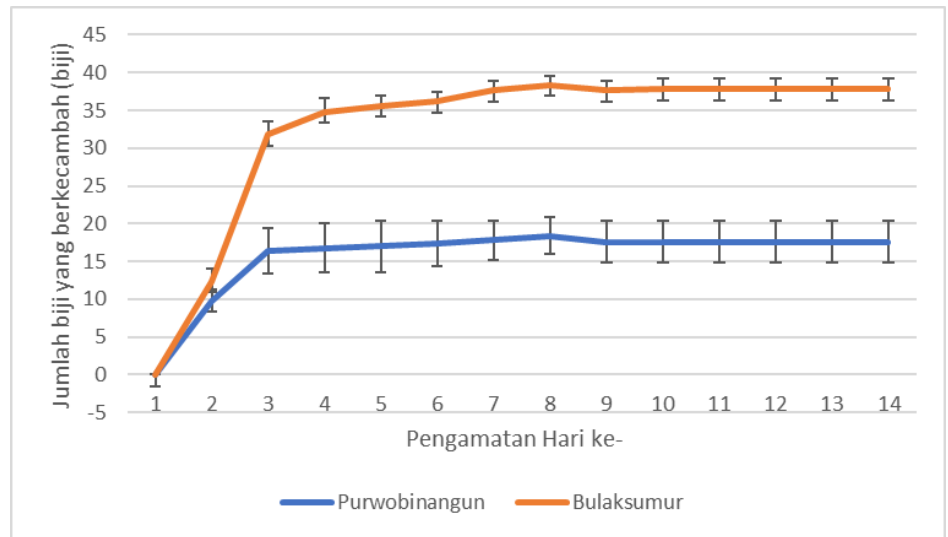

Gambar 1. Perbandingan viabilitas biji dari pohon induk timoho di Purwobinangun dan Bulaksumur pada media petri dish

Gambar 1 menunjukan bahwa pada petri dish, biji timoho dari Bulaksumur memiliki viabilitas atau daya kecambah yang lebih tinggi daripada biji timoho dari Purwobinangun yang ditunjukkan dengan rata-rata biji yang berhasil berkecambah sebanyak 35 biji dari Bulaksumur, dan 20 biji dari Purwobinangun.

Tabel 2. Indeks perkecambahan biji timoho dari Bulaksumur dan Purwobinangun

\begin{tabular}{clccc}
\hline \multirow{2}{*}{ Habitat } & \multicolumn{2}{c}{ Indeks } & \multicolumn{2}{c}{$\mathrm{T}$} \\
\cline { 2 - 5 } & DK & KCT & Awal & Akhir \\
\hline Bulaksumur & $80 \%$ & 2,5 hari & 13 biji & 101 biji \\
Purwobinangun & $68 \%$ & 2,4 hari & 49 biji & 88 biji
\end{tabular}

Keterangan :

DK = Daya kecambah / Viabilitas

KCT = Kecepatan perkecambahan

$\mathrm{T}=$ Waktu perkecambahan

Hasil perhitungan (Tabel 2) menunjukkan viabilitas biji timoho dari Bulaksumur sebesar $80 \%$ dengan kecepatan berkecambahnya rata-rata selama 2,5 hari, perkecambahan awal sebanyak 13 biji hingga diakhir pengamatan terdapat 101 biji yang berhasil berkecambah, sedangkan biji timoho dari Purwobinangun memiliki viabilitas sebesar $68 \%$, dengan kecepatan berkecambahnya rata-rata selama 2,4 hari, perkecambahan awal sebanyak 49 biji dan di akhir pengamatan terdapat 88 biji yang berhasil berkecambah. Berdasarkan hal tersebut, diketahui bahwa biji timoho dari Bulaksumur memiliki potensi untuk berkecambah lebih tinggi dibandingkan biji dari Purwobinangun, sehingga akan menghasilkan biji yang berhasil berkecambah lebih banyak. Namun demikian, biji dari Bulaksumur membutuhkan waktu yang sedikit lebih lama untuk berkecambah dibandingkan biji dari Purwobinangun (Gambar 1).

Jika dikaitkan dengan parameter fisikokimia, kemungkinan penyebab daya kecambah (viabilitas) biji timoho dari 
Bulaksumur lebih baik dibandingkan Purwobinangun adalah nilai kelembaban udara Bulaksumur lebih tinggi. Meskipun suhu udara di Bulaksumur lebih panas, intensitas cahaya yang masuk ke tajuk pohon lebih rendah sehingga udaranya menjadi lebih lembab, kondisi ini merupakan kondisi yang lebih sesuai untuk pertumbuhan biji timoho. Pernyataan tersebut dapat diketahui melalui hasil panen biji timoho pada kedua habitat pohon induk. Hasil panen biji timoho dengan berat $10,18 \mathrm{~g}$ menghasilkan jumlah biji Bulaksumur lebih banyak yaitu 1025 biji, sedangkan pada Purwobinangun hanya didapatkan 967 biji. Mengacu pada data kelembaban Tabel 1 menunjukan bahwa nilai kelembaban di sekitar pohon induk Bulaksumur mencapai angka $36,00 \%$, nilai tersebut lebih tinggi dibandingkan dari pohon induk yang berada di Purwobinangun dengan nilai kelembaban $34,67 \%$. Berdasarkan nilai kelembaban yang didapatkan kemungkinan faktor tersebut yang menyebabkan tanah di Bulaksumur lebih subur dibandingkan dengan di Purwobinangun. Penelitian yang telah dilakukan Susanto dan Baskorowati (2018) menunjukkan perbedaan kesuburan tanah akan mempengaruhi pertumbuhan pohon melalui metabolisme pohon dan berbagai proses fisiologis yang terkait dengan pertumbuhan pohon itu sendiri.

Biji timoho dari yang berasal dari pohon induk di Purwobinangun memiliki kulit biji yang lebih lunak sehingga proses pematahan dormansi lebih mudah terjadi. Dengan demikian, terdapat kemungkinan proses perendaman air panas selama 24 jam menjadi terlalu lama untuk kulit biji timoho dari Purwobinangun, sehingga berpotensi merusak sebagian embrio biji. Hal tersebut menjadi salah satu kemungkinan penyebab sebagian biji dari Purwobinangun tidak berkecambah.

\section{Pembibitan timoho di persemaian}

Proses perkecambahan dalam media petri dish dilanjutkan dengan pertumbuhan bibit ke dalam polybag. Bibit yang dapat dipindahkan ke dalam media polybag merupakan bibit yang sudah memenuhi kriteria pemindahan meliputi panjang daun mencapai $5 \mathrm{~cm}$ dan bibit sudah memiliki daun dengan jumlah minimal 2 . Apabila seluruh kriteria pemindahan sudah dicapai maka bibit timoho dapat dipindahkan ke dalam media polybag. Media yang digunakan pada polybag terdiri dari kompos, pasir, dan tanah dengan perbandingan volume berturutturut 3:1:1. Saat berada di polybag, bibit diberi sungkup dengan bahan plastik guna menjaga kelembaban udara sekaligus untuk mencegah kerusakan oleh hama pada bibit. Pemindahan ini dilanjutkan dengan proses pengamatan dan perhitungan panjang batang bibit serta jumlah daun dua minggu sekali selama 42 hari. Berdasarkan pengukuran yang dilakukan, didapatkan hasil sebagaimana disampaikan di Gambar 2 (untuk jumlah daun) dan Gambar 3 (untuk panjang batang).

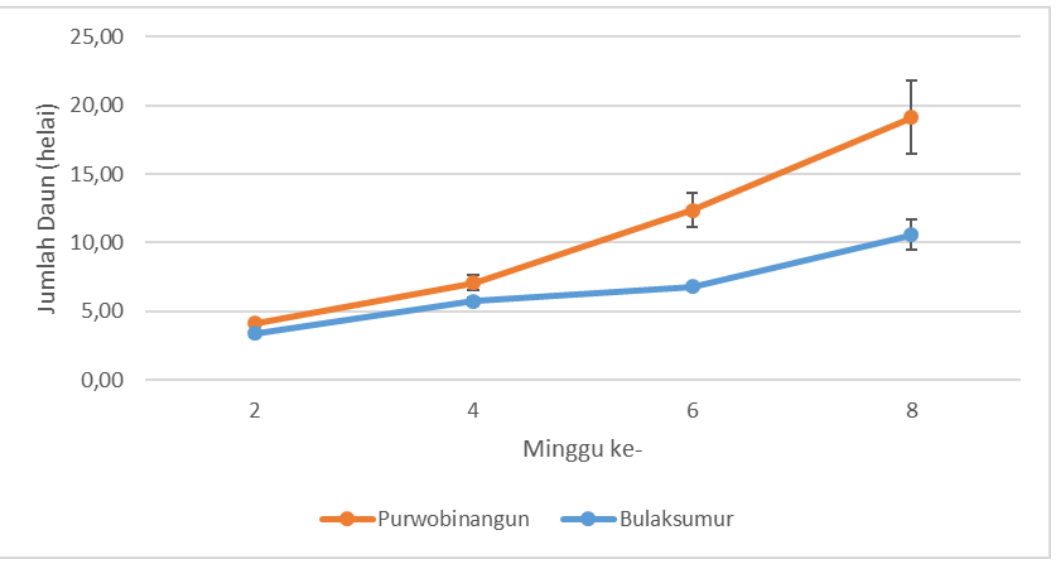

Gambar 2. Perbandingan jumlah daun bibit timoho dari Bulaksumur dan Purwobinangun 
Berdasarkan Gambar 2 dapat dilihat bahwa tren jumlah daun bibit timoho dari pengamatan terakhir jika dibandingkan dengan rata-rata jumlah daun bibit timoho dari Bulaksumur yang hanya $10,59 \pm 1,07$ helai. Sementara itu, pada gambar 3 dapat dilihat bahwa bibit timoho dari Purwobinangun memiliki tren rata-rata penambahan panjang
Purwobinangun memiliki rata-rata jumlah daun lebih banyak, yaitu 19,11 $\pm 2,66$ helai pada batang yang lebih tinggi, yaitu 11,54 $\pm 2,77 \mathrm{~cm}$ pada pengamatan terakhir, jika dibandingkan dengan tren penambahan panjang batang bibit timoho dari Bulaksumur sepanjang 7,59 $\pm 1,17$ $\mathrm{cm}$ pada pengamatan terakhir.

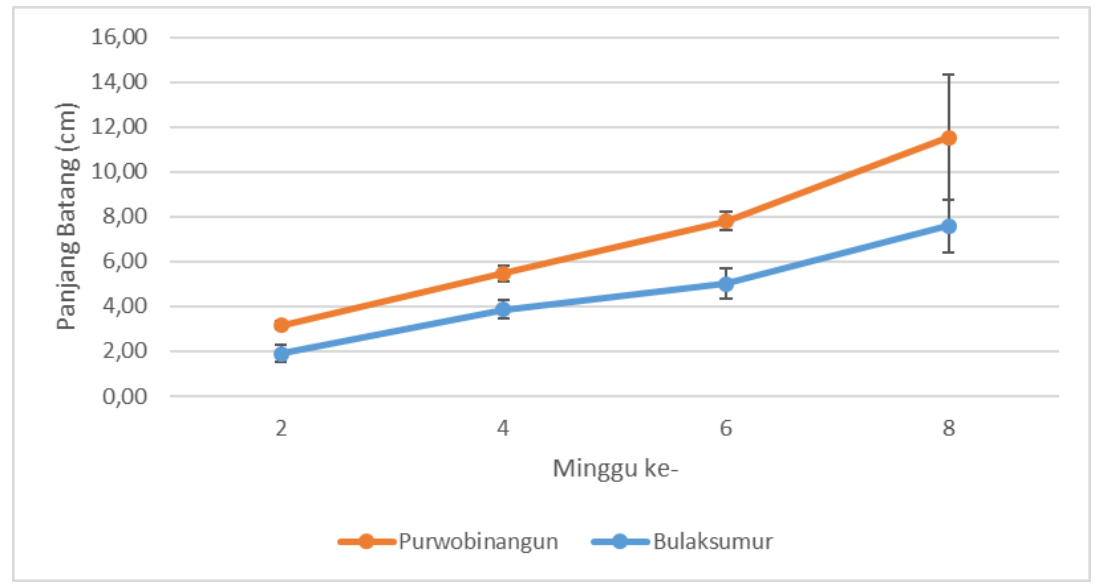

Gambar 3. Perbandingan panjang batang bibit timoho dari Bulaksumur dan Purwobinangun

Selama proses persemaian, didapatkan bahwa jumlah daun dan panjang batang bibit timoho dari Purwobinangun lebih tinggi dibandingkan dengan Bulaksumur. Hal tersebut berbanding terbalik dari hasil daya kecambah biji, dimana timoho dari Bulaksumur memiliki daya kecambah lebih tinggi dibandingkan Purwobinangun. Perkembangan kedua biji tersebut dimungkinkan sebagai hasil dari kualitas biji timoho pada kedua pohon indukan. Telah disebutkan bahwa pohon induk yang terdapat pada lokasi Purwobinangun dan Bulaksumur memiliki jumlah individu yang berbeda. Terdapat dua pohon timoho yang berdekatan di Purwobinangun, sedangkan di Bulaksumur hanya terdapat satu pohon timoho. Sehingga berdasarkan kondisi tersebut menunjukkan bahwa terdapat kemungkinan besar biji timoho dari Bulaksumur adalah hasil dari kawin silang (selfing). Selfing merupakan pemuliaan yang dilakukan oleh individu tanaman secara mandiri yang menghasilkan galur murni dengan sifat seragam (Mahayu \& Novarianto, 2014). Selfing berbahaya untuk sebagian besar spesies tanaman karena dapat meningkatkan kemungkinan bergabungnya alel resesif dan letal, sehingga akan menghasilkan homozigot dengan sifat yang berbahaya, hal tersebut akan berakibat pada karakteristik tanaman yang lebih buruk, misalnya tanaman menjadi kerdil dan rentan terhadap penyakit atau sifat-sifat lain yang tidak diinginkan (Pierce, 2012). Penelitian yang dilakukan oleh Wulan, Yulianah, dan Damanhuri (2017) menunjukan bahwa selfing pada tanaman jagung mengakibatkan terjadinya depresi silang dalam sehingga jagung yang dihasilkan memiliki karakteristik tinggi tanaman dan bobot tongkol yang rendah. Penelitian lain yang dilakukan oleh Hussein dan Mohammed (2018) juga menunjukan hasil serupa bahwa selfing yang terjadi pada tanaman jagung mengakibatkan kekerdilan dengan tinggi batang hanya mencapai $130,71 \mathrm{~cm}$ sedangkan tanaman induk memiliki tinggi batang mencapai $145,20 \mathrm{~cm}$ sampai dengan 175,67 cm. Penurunan karakter pada tanaman yang melakukan selfing diakibatkan karena munculnya gen-gen resesif dengan sifat homozigot yang terekspresikan pada tanaman. Oleh karena itu, selfing 
mengakibatkan tanaman memiliki kualitas yang buruk ditunjukkan dengan penurunan karakter unggul pada tanaman tersebut.

Hal yang sama terjadi pada pohon indukan yang berada di Bulaksumur. Berdasarkan jumlah pohon indukan yang terdapat di Bulaksumur terdapat kemungkinan bahwa pohon tersebut melakukan selfing. Sehingga kualitas anakan yang dihasilkan dari pohon indukan di Bulaksumur memiliki kualitas yang lebih rendah. Sebaliknya keadaan yang berbeda ditemukan pada dua pohon timoho yang berada di Purwobinangun kemungkinan besar melakukan perkawinan silang antar keduanya sehingga kecil kemungkinan untuk melakukan selfing. Dengan demikian dapat diasumsikan bahwa selfing menyebabkan pohon timoho dari Bulaksumur menghasilkan keturunan yang kurang baik jika dibandingkan dengan pohon timoho dari Purwobinangun yang kemungkinan tidak melakukan selfing.

\section{KESIMPULAN}

Hasil penelitian ini menunjukkan viabilitas biji dari pohon induk timoho di Bulaksumur (80\%) lebih tinggi dari Purwobinangun (68\%), namun tingkat pertumbuhannya lebih rendah dibandingkan biji dari Purwobinangun. Jumlah daun bibit timoho dari Purwobinangun memiliki rata-rata jumlah daun $(19,11 \pm 2,66$ helai) dan panjang batang $(11,54 \pm 2,77 \mathrm{~cm})$ lebih baik dibandingkan dengan rata-rata jumlah daun dan panjang batang bibit timoho dari Bulaksumur (10,59 $\pm 1,07$ helai dan 7,59 $\pm 1,17$ $\mathrm{cm})$. Meskipun memerlukan penelitian lebih lanjut, hasil penelitian ini menunjukkan bahwa bibit yang diperoleh merupakan hasil sistem perkawinan yang tidak acak.

\section{UCAPAN TERIMA KASIH}

Ucapan terima kasih disampaikan kepada semua pihak yang telah membantu kelancaran penelitian ini baik dari Fakultas Biologi UGM maupun B2P2BPTH Yogyakarta, terutama para peneliti yang tergabung dalam tim litbang jenis khas DIY yang telah membantu dalam kegiatan penelitian di Persemaian B2P2BPTH Yogyakarta.

\section{DAFTAR PUSTAKA}

Arung, E. T., Kusuma, I. W., Purwatiningsih, S., Roh, S., Yang, C. H., Jeon, S., Kondo, R. (2009). Antioxidant Activity and Cytotoxicity of the Traditional Indonesian Medicine Tahongai (Kleinhovia hospita L.) Extract. https://doi.org/10.1016/S20052901(09)60073-X

BLH. (2016). Profil Keanekaragaman Hayati Daerah Istimewa Yogyakarta Tahun 2016. Yogyakarta.

Deb, P., \& Sundriyal, R. C. (2017). Effect of seed size on germination and seedling fitness in four tropical rainforest tree species. Indian Journal of Forestry, 40(4), 313-322.

Djabir, Y. Y., Arsyad, M. A., Sartini, S., \& Lallo, S. (2017). Potential roles of Kleinhovia hospita L. leaf extract in reducing doxorubicin acute hepatic, cardiac and renal toxicities in rats. Pharmacognosy Research, 9(2), 168-173. https://doi.org/10.4103/pr.pr

Farhana, B., Ilyas, S., \& Budiman, L. F. (2013). Pematahan Dormansi Benih Kelapa Sawit (Elaeis guineensisJacq.) dengan Perendaman dalam Air Panas dan Variasi Konsentrasi Ethephon. Buletin Agrohorti, 1(1), 72-78. https://doi.org/10.29244/agrob.1.1.72-78

Hakim, L., Yuliah, \& Adinugraha, A. (2019). Pengaruh Pohon Induk dan Bahan Stek Terhadap Pertumbuhan Stek Cabang Timoho (Kleinhovia hospita L) Effect of mother trees and cuttings material on the growth of timoho (Kleinhovia hospita L.) stem cuttings. Jurnal Pemuliaan Tanaman Hutan, 13(2), 60.

Hussein, Z. T., \& Mohammed, A. O. (2018). Relationship between Selfing Generations and Hybrid Vigor in Maize (Zea mays L.). Journal of Plant Production, 9(1), 7-12. https://doi.org/10.21608/jpp.2018.35231

Indrawan, M., Primack, R. B., \& Supriatna, J. (2007). Biologi konservasi. Jakarta: Yayasan Obor Indonesia.

Kehati, D. (2017). Keanekaragaman Hayati Daerah Istimewa Yogyakarta. Retrieved from http://kehati.jogjaprov.go.id/

Kusmana, C., \& Hikmat, A. (2015). The Biodiversity of Flora in Indonesia. Journal of Natural Resources and Environmental Management, $5(2)$, 187-198. https://doi.org/10.19081/jpsl.5.2.187 
Mahayu, W. M., \& Novarianto, H. (2014). Karakteristik Generasi Selfing Kelapa Dalam Mapanget untuk Seleksi Pohon Induk Sumber Polen. Buletin Palma, 15(1), 24-32. https://doi.org/10.21082/bp.v15n1.2014.2432

Mashudi, Setiadi, D., \& Surip. (2005). Aplikasi Variasi Media Perkecambahan Pada Persemaian Pulai (Application of germination media variation of pulai nursery). Jurnal Penelitian Hutan Tanaman, 2(1), 13-19.

Njurumana, G. N., Marsono, D., Irham, \& Sadono, R. (2014). Konservasi keanekaragaman hayati tanaman pada sistem kaliwu di pulau Sumba. J. Manusia Dan Lingkungan, 21(1), 75-82.

Pierce, B. A. (2012). Genetics: A Conceptual Approach (4 th ed). New York (US): W. H. Freeman and Company.

Portal, I. I. (2018). Keanekaragaman hayati Indonesia, negara megabiodiversitas.

Putra, H. F., Ambarwati, D. S., Mubyarsih, N., \& Alesti, T. (2015). Karakteristik Fisiologis Lumut pada Beberapa Ketinggian di Kawasan Gunung Tangkuban Perahu. Jurnal Sumberdaya Hayati, 1(2), 60-63.

Romadloni, A., \& Wicaksono, P. (2018). Pengaruh Beberapa Level Salinitas Terhadap Perkecambahan Kacang Hijau (Vigna radiata L.) Varietas Vima 1 The Effect On Some Level Saline Germination On Greenbean (Vigna radiata L.) Vima 1 Variety. Jurnal Produksi Tanaman, 6(8), 1663-1670.
Sandi, A. L. I., Indriyanto, \& Duryat. (2014). Ukuran benih dan skarifikasi dengan air panas terhadap perkecambahan benih pohon kuku (Pericopsis Mooniana). Jurnal Sylva Lestari, 2(3), 83. https://doi.org/10.23960/js13283-92

Situmeang, M., Purwantoro, A., \& Sulandari, S. (2014). Pengaruh Pemanasan Terhadap Perkecambahan dan Kesehatan Benih Kedelai (Glycine $\max$ (L.) Merrill). Vegetalika, 3(3), 27-37. https://doi.org/10.22146/veg.5156

Suhartati, \& Alfaizin, Di. (2017). Perkecambahan benih Pericopsis mooniana Thw. berdasarkan warna dan teknik skarifikasi. Jurnal Perbenihan Tanaman Hutan, 5(2), 115-124. https://doi.org/10.20886/bptpth.2017.5.2.115124

Susanto, M., \& Baskorowati, L. (2018). Pengaruh genetik dan lingkungan terhadap pertumbuhan sengon (Falcataria molucanna) Ras Lahan Jawa. Bioeksperimen: Jurnal Penelitian Biologi, 4(2), 35-41. https://doi.org/10.23917/bioeksperimen.v4i2. 6883

Sutoyo. (2010). Keanekaragaman Hayati Indonesia Suatu Tinjauan : Masalah dan Pemecahannya. Buana Sains, 10(2), 101-106.

Wulan, W. P. N., Yulianah, I., \& Damanhuri. (2017). Penurunan ketegaran (inbreeding depression) pada generasi $\mathrm{F} 1, \mathrm{~S} 1$ dan $\mathrm{S} 2$ populasi tanaman jagung (Zea mays L.). Jurnal Produksi Tanaman, 5(3), 521-530. 